\title{
ВЕРБАЛІЗАЦІЯ КОНЦЕПТУ ДІМ В УКРАЇНСЬКІЙ, РОСІЙСЬКІЙ I ПОЛЬСЬКІЙ МОВАХ
}

\author{
ЮЛІЯ ЛЕБЕДЕНКО, ЯНА ВАСИЛЕНКО
}

Харківський національний педагогічний університет імені Г. С. Сковороди, Харків - Україна

\author{
WERBALIZACJA KONCEPTU DOM \\ W JĘZYKU UKRAIŃSKIM, ROSYJSKIM I POLSKIM
}

JULIA LEBEDENKO, JANA WASYLENKO

Charkowski Narodowy Uniwersytet Pedagogiczny imienia Hryhorija Skoworody, Charków - Ukraina

STRESZCZENIE. Artykuł poświęcony jest analizie konceptu „dom” w ukraińskim, rosyjskim oraz polskim językowym obrazie świata. Bazując na językowych zasobach ukraińskiej, rosyjskiej i polskiej idiomatyki zostały wyodrębnione semantyczne komponenty konceptu „dom”, wyszczególnione odcienie znaczeniowe i uniwersalie kulturowe.

\section{VERBALIZATION OF THE CONCEPT HOME IN UKRAINIAN, RUSSIAN AND POLISH}

\section{YULIA LEBEDENKO, YANA VASYLENKO,}

Kharkiv H. S. Skovoroda National Pedagogical University, Kharkiv - Ukraine

ABSRACT. The article deals with the investigation of the concept "home" in Ukrainian, Russian and Polish. Semantic constituents, cultural universals of the concept "home" have been determined, basing on the material of Ukrainian, Russian and Polish phraseological units.

$\mathrm{O}$ дним із завдань сучасного мовознавства $є$ осмислення мовних і мовленнєвих фактів крізь призму лінгвокультурологічних методів аналізу ключових слів, що формують мовну картину світу.

Процеси отримання, зберігання й передачі знань про світ здійснюються в типових для певної мови концептах. Характерний для мови спосіб концептуалізації дійсності має національну специфіку, оскільки, як відомо, носії різних мов по-різному бачать світ.

На думку В. Карасика і Г. Слишкіна, лінгвокультурний концепт становить умовну ментальну одиницю, спрямовану на комплексне вивчення мови, свідомості та культури ${ }^{1}$ В. Маслова співвідносить культурні концепти 3 назвами абстрактних понять, у яких культурна інформація прикріплюється до понятійного ядра ${ }^{2}$. С. Воркачов уважає, що лінгвокультурний концепт $\epsilon$ семантичним утворенням високого ступеня абстрактності, тобто $є$ продуктом абстрагування семантичних ознак, що належать певній кількості значущих

${ }^{1}$ В. И. Карасик, Г. Г. Слышкин, Лингвокультурный концепт как единица исследования, [в:] Методологические проблемы когнитивной лингвистики, под ред. И. А. Стернина, Воронеж 2001, c. $75-80$.

${ }^{2}$ В. А. Маслова, Лингвокультурология, Москва 2001, с. 48. 
мовних одиниць ${ }^{3}$. Отже, лінгвокультурні концепти - це базові одиниці мовної картини світу, в яких зафіксовані цінності як окремої мовної особистості, так і лінгвокультурної спільноти загалом. Концепт, як відомо, складається 3 компонентів, тобто концептуальних ознак, i, за визначенням Ю. Степанова, має ярусну будову ${ }^{4}$. Кожен концепт як складний ментальний комплекс, крім змісту, виражає й оцінне ставлення людини, об'єкта відображення, тому під час його інтерпретації враховуємо насамперед наявність загальнолюдського компонента, а також національно-культурного й соціального, розрізняємо групові та індивідуально-особистісні компоненти ${ }^{5}$.

Концепти реалізуються в мовній практиці, в конкретному тексті. I тільки дослідження якомога більшої кількості текстів дасть змогу визначити в повному обсязі семантичне й культурне поле концепту. Фразеологія (в широкому iii розумінні) є благодатним грунтом для реалізації концепту.

Назви типів житлових будівель - це такий лексичний пласт, що змінюється лише після втрати реалії. Констатуємо, що він майже не змінився з XVII ст., зокрема в давньоруських текстах домь як, „будівля” відоме вже 31230 р., як „житло” — 3 XIII століття.

Концепт „дім (житло)” неодноразово ставав предметом дослідження в етнографічному та культурологічному аспектах (А. Байбурин, А. Будилович, Н. Воронін, Д. Зеленін, О. Козирева, Ю. Степанов та ін.), а також літературознавчому (О. Ланська, М. Литовченко, А. Медведєва, А. Разувалова, О. Фещенко, Є. Шульман та ін.). Мовний матеріал, що став джерелом цього дослідження, дає змогу виявити структуру й місце концепту „дім” у національних мовних картинах світу українців, росіян та поляків.

Мета дослідження - окреслити універсалії, що виокремлюються в процесі визначення місця концепту ,дім” у мовній картині світу трьох названих народів.

Безумовно, українські, російські й польські лінгвокультури мають як свої специфічні риси, так і спільні. Дослідження національної концептосфери $\epsilon$ одним із способів з'ясування унікальності та універсальності цих культур, виділення споконвічного й запозиченого.

Словникові значення слова, дім” в українській, російській та польській мовах частково збігаються. У тлумачному Словнику украӥнської мови в 11-ти томах подано 4 значення слова ,дім”: 1. Будівля, призначена для житла або для розміщення різних установ; будинок. 2. Приміщення, в якому живуть люди, житло. 3. Приміщення, люди, які в ньому живуть та їх господарство. 4. Монархи одного роду, які послідовно замінювали один одного ${ }^{6}$. У тлумачному словнику російської мови за редакцією Д. М. Ушакова міститься шість значень цього слова: 1. Житлова будівля, будова; 2. Житлове приміщення, квартира; 3. Династія, рід; 4. Заклад для обслуговування культурно-побутових потреб працівників або окремого кола осіб, розмішених зазвичай в окремій будівлі; 5. Заклад, підприємство; 6. У деяких дитячих іграх, заснованих на переслідуванні (п’ятнашки, схованки та ін.), місце, де за правилами не можна переслідувати ${ }^{7}$. У тлумачному

${ }^{3}$ С. Г. Воркачёв, Лингвокультурный кониепт: типология и области бытования, Волгоград, 2007.

${ }^{4}$ Ю. С. Степанов, Константы: Словарь русской культуры. Опыт исследования, Москва 1997, c. 41.

${ }^{5}$ Там само, с. 42.

${ }^{6}$ Словник української мови, в 11 тт., Київ, 1970, т. 2; Словник фразеологізмів української мови, уклад. В. М. Білоноженко та ін., Київ 2003.

${ }^{7}$ Толковый словарь русского языка, под ред. проф. Д. Н. Ушакова, в 4 тт., Москва 1935, т. 1, c. $759-760$. 
словнику польської мови маємо таке: 1. Будинок, будівля, що служить місцем помешкання, місце розміщення установ, магазинів, закладів праці тощо; 2. Помешкання, житлове приміщення; 3. Найближча родина, домашні, які живуть разом; 4. Родинні справи, заняття й домашні обов'язки; домашнє господарство; 5. Родинна династія, рід; 6. Назва однієї з найбільших установ, що займає зазвичай окремий будинок; а також назва (або частина назви) будинку, в якому розміщена така установа; заклад, підприємство, садиба ${ }^{8}$.

У літературних варіантах кожної з досліджуваних мов, як бачимо, слово „дім” позначає родове поняття й асоціюється в мовній свідомості 3 кам'яною або цегляною будівлею, співвідноситься 3 лексемами хата (укр., рос., пол.), будинок (укр., рос., пол.), изба (рос.).

Щодо видових понять, пов'язаних зі словом ,дім”, найбільш близькими в українській мові є хата, домівка, квартира, житло, кам'яниця, горниия, халупа, хижа і т. ін.; у російській - жильё, изба, избушка, хата, горница, nалаты, хоромы, терем тощо; в польській — domek, budowla, budynek, mieshkanie, kamienica, chata та ін.

У кожній із досліджуваних мов лексема „дім” має низку дериватів на позначення житлової споруди, наприклад: домик, домок, домичок, домочок - зменш.пест. до „дім”; домівка — „помешкання, житло”; домовина — „труна, могила" (за релігійними переконаннями — „житло померлого”) (укр.) / домашность — „жилой дом со всеми хозяйственными пристройками”; домовина - 1. "дом, постоянное жилье (в отличие от летника и зимника)”, 2. „гроб”. 3. „сооружение, сруб в виде гроба над могилой”; домовище - 1. „жилище злых духов”. 2. „гроб”. 3. В суеверных представлениях — „омут, в котором живет водяник (дух)”; домовка - 1. „дом, жилище”. 2. „хозяйство”. 3. „могила”; домишко - уничижит. или уменьшит. „дом со всем хозяйством”; домина - разговор. „большой дом” (рос.); домилище - устар. „жильё, жилище, жительство, помещение"/ domek, domeczek — pieszczotliwie o domu rodzinnym, zdrobn. od „dom”; domisko — zgrub. od „dom”.

Концептуальне поле формують зокрема близькоспоріднені поняття, серед яких укажемо такі: в українській мові - домашній, домогосподарка, додому, домовик, домова, домофон та ін.; у російській - дома, домашний, домамность, домой, домострой, домовыцй, домовой, домовик, домовая, домовньй, домовитый, домовитость, домовладелеи, домовладение тощо; у польській domator (-ka), domatorstwo, domek, domeczek, domofon, domorosty, domostwo, domowina, domowizna, domownicy, domowy (-a, -e), podomka та ін.

Найважливіша функція дому - захисна, оберегова. Це має вияв насамперед у фразеології, що відбиває світогляд і переконання народу, наприклад: Свій дім не ворог: коли прийдеш, то прийме / И стень в доме помогают / $W$ swojem domu (chate) nawet dym słodki. Отже, дім асоціюється з власним простором, відмежованим від довкілля, але він і пов'язує людину із цим світом. Отже, дім $\epsilon$ центром тріади: дім - людина - світ. Структура дому подібна до структури зовнішнього світу: дім — це світ, що відповідає основним потребам людини і створений нею самою.

На фразеологічному матеріалі виокремлюємо концептуальні універсалії, що виявляються в усіх трьох досліджуваних мовах, наприклад: 1) дім - гостинність: Просимо до дому (хати), Чим хата багата, тим і рада / Не красна изба углами, красна пирогами / Czyj dom jest dla kogo otwarty; Czynić, pet-

\footnotetext{
${ }^{8}$ Stownik wspótczesnego języka polskiego, Przegląd, Warszawa 2001, t. 1, s. 186-187.
} 
nić honory domu; 2) повага до господарів дому: Чия xama, того й правда / Что поставят, то и кушай, а хозяина дома слушай / Gdy jesteś w cudzym domu, nie zawadzajże nikoти; 3) дім - осередок родини: рідний дім; отчий дім; таткова хата усім багата, родинне гніздо, батьківська хата / родительський дом, отчий дом, домашний очаг, родительское гнездо / ognisko domowe, rodzinne; gniazdo rodzinne; dach rodzinny; strzecha rodzinna; ojczysta srzecha; 4) важливість власного житла: Бодай і пес свою хату мав, Не пізно до свого дому і опівночі / В гостях хорошо, а дома лучше; В своём доме и солома съедома / Wolnoć Tomku w swoim domku; 5) важливість господаря / господарки в домі: Хазяйка в дому покрова всьому; Без господаря і двір плаче, а без господині-хата / Без хозяина двор и сыр, и вдов; Хозяйка в дому - что оладьи в меду / Вус́ рапет we wtasnym domu; pan domu, pani domu; 6) дім - відображення фінансового становища господаря: Недостатки гонять з хатки (бідність); Купуй сукню шиту, а хату криту (багатство); I кішки в домі нема (бідність) / Дом, как полная чаша (богатство); У него в доме нечем собаки заманить (бедность) / Prowadzić dom, żyć na niskiej stopie (bieda), Prowadzić dom, żyć na wysokiej stopie (bogactwo).

Універсальні особливості світосприйняття трьох народів виявляються в розподілі акцентів між двома концептуальними шарами, а саме: „дім” і „бути дома”, що складають концепт „дім”.

Концептуальний шар „дім” містить когнітивні прошарки, що входять до структури загальномовного концепту: 1) місце проживання: Як не мають домів, щоб іщастянемали /Цыганскийдом: три кола дапосерединіголовня/Gоść $w$ dom, Bóg $w$ dom 2) приміщення, люди, які в ньому живуть, та їх господарство: Свій дім - не ворог: коли прийдеш, то прийме / Дом вести - не лапти плести / Postawić cały dom na nogi 3) суспільна установа: божсий дім, жовтий дім, публічний дім тощо / дом культуры, дом терпимости, сумасшедший дом та ін. / dom modlitwy, dom pracy twórczej, dom żałoby і т. ін.; 4) родина, династія: иарський дім (розміщався в Зимовому палаиі) / Дом Романовых / potomek królewskiego dоти (про поважну, добру родину, рід).

Концептуальний шар „бути вдома” виявляється насамперед у двох аспектах: бути у власному домі, почуваючись при цьому вільно й затишно, або перебувати в чужому домі, що визначає напружений внутрішній стан і відповідну поведінку людини, наприклад: Лучче дома, ніж на празнику / Дома - не в гостях, посидев, не уйдёшь / W cudzym doти nie zawadzajźe nikomu.

Найважливіше місце в концепті „дім” посідає асоціат сім'я, родина, порівн.: Хазяйка в дому, покрова всьому / Всякий дом хозяином держится / Pan (-i) doти . Крім того, визначальною в структурі концепту виявляється лексико-семантична група „призначення” (дім - фортеця, прихисток, захист, пристанище, надійність): Дома й стіни допомагають / Всего дороже честь сытая да изба крытая / Ojcowska strzecha, dach nad głowq. У слов'янській мовній картині світу дім постає найважливішою цінністю (родина, нерухоме майно, господарство, порядок у побуті): Всюди гаразд, а дома найліпме; Згода дім будує; Постав мені хату з лободи, а в чужую не веди / Двор что город, изба что терем; Надо меньше есть, да свое иметь, меньше пить, да свое купить; Всем домом собраться / Zachowywać sięak w domu; załoźyć dom, rodzine.

У досліджуваних фразеологічних одиницях визначимо базові для характеристики дому опозиції: „свій — чужий”, „господар — гість”, „багатство бідність”, „лінь — працелюбство”, „дім — дорога”, „порядок — безлад”. 
Отже, в українській, російській та польській мовних картинах світу концепт „дім” посідає важливе місце, оскільки $\partial і м$ - найважливіша й необхідна складова існування людини. Дім сприймають не лише як реальний об'єкт, житлову споруду, але і як родину, господу, тепло й оберіг.

В українських, російських та польських фразеологізмах, що становлять вагому складову концептуального поля „дім”, визначено низку універсалій: diм - гостинність; повага до господарів дому; дім - осередок родини; важливість власного житла; обов'язкова наявність гарного господаря (господарки); diм - відображення фінансового становища господаря. Наявні в мовній свідомості трьох народів універсалії є запорукою взаєморозуміння й взаємоповаги між спорідненими народами.

Хоч у структурі фразеологізмів міститься значна кількість слів 3 негативною конотацією, в слов'янській мовній картині світу домінують уявлення про необхідність мати своє житло.

Отже, у статті репрезентовано концепт „дім”, основними ознаками якого $\epsilon$ уявлення про захищене, вільне житло, заселене людьми, які сприймають його як власний простір. 